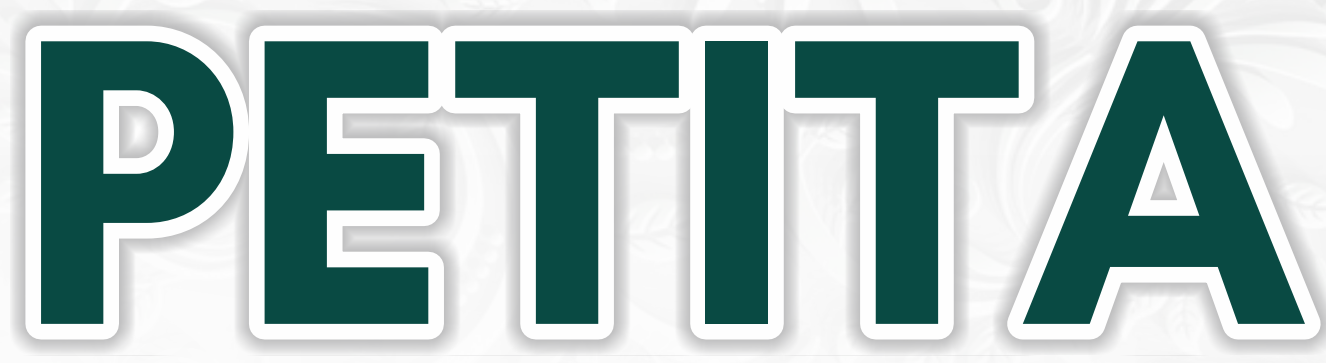

Jurnal Kajian Ilmu Hukum dan Syariah

Published By:

Lembaga Kajian Konstitusi Indonesia (LKKI)

Fakultas Syariah dan Hukum Universitas Islam Negeri (UIN) Ar-Raniry Banda Aceh Jl. Syeikh Abdul Rauf, Kopelma Darussalam Banda Aceh, Telp: 0651-7557442 Website: http://petita.ar-raniry.ac.id 


\section{Contents}

EKSISTENSI BITCOIN DALAM PERSPEKTIF MAQĀṢID AL-SYAR'ĪYAH

(Dara Lidia, Jabbar Sabil \& Syarifuddin Usman / 104-113)

TATACARA PENETAPAN BATAS TANAH DIKALANGAN MASYARAKAT KECAMATAN BAKONGAN TIMUR DITINJAU MENURUT KONSEP MAL 'UQAR

(Elida Gusmira, Saifuddin Sa'dan \& Faisal Fauzan / 114-127)

TINJAUAN HUKUM ISLAM TERHADAP SISTEM PENYELESAIAN WANPRESTASI PRODUK ARRUM DI PEGADAIAN SYARIAH ACEH BESAR

(Asdi Marni, Edi Darmawijaya \& Faisal Fauzan / 128-136)

SANKSI ADAT BAGI PELAKU KEKERASAN FISIK DITINJAU MENURUT HUKUM PIDANA ISLAM (Studi Terhadap Adat Kampung Taman Firdaus, Kecamatan Pintu Rime Gayo, Kabupaten Bener Meriah)

(Abdul Rahman, Jamhuri \& Irwansyah / 137-144)

DAMPAK PEMEKARAN DAERAH PADA PELAYANAN PUBLIK DITINJAU MENURUT SISTEM HUKUM INDONESIA

(Ali Abubakar, Sitti Mawar \& Nurdin Syah / 145-155)

MARK UP PENJUALAN HARGA TIKET BUS PADA LOKET TERMINAL BATOH DALAM PERSPEKTIF TAS'IR AL-JABAR (Studi tentang Penyimpangan Harga Dari Ketetapan Organda Banda Aceh)

(Aris Rahmaddillah / 156-169)

PROSES PENIMBANGAN IKAN DI TEMPAT PELELANGAN IKAN LAMPULO KOTA BANDA ACEH DALAM PERSPEKTIF MA'QUD 'ALAIH

(Alfata / 170-175)

SANKSI BAGI PELAKU ZINA (Perbandingan Qanun No. 6 Tahun 2014 Dan Enakmen Jenayah Syariah Negeri Selangor No. 9 Tahun 1995 Seksyen 25)

(Ali Abubakar, Badrul Munir \& Cempaka Sari Harahap / 176-200) 
PETITA: Jurnal Kajian Ilmu Hukum dan Syariah

Volume 3, Number 2, 2018

P-ISSN: 2502-8006 E-ISSN: 2549-8274

DOI: https://doi.org/10.22373/petita.v3i2.51

\title{
MARK UP PENJUALAN HARGA TIKET BUS PADA LOKET TERMINAL BATOH DALAM PERSPEKTIF TAS'IR AL-JABARI \\ (Studi tentang Penyimpangan Harga Dari Ketetapan Organda Banda Aceh)
}

\author{
Aris Rahmaddillah \\ Hukum Ekonomi Syariah Universitas Islam Negeri Ar-Raniry \\ Email: arisrahmaddillah@gmail.com
}

\begin{abstract}
The price of bus tickets varies based on the facilities offered by the bus company. The passengers can choose the bus, either the regular or luxury coaches and the bus ticket prices have been agreed by the Organization Land Transportation (ORGANDA). This study focused on the system of determining bus ticket prices at the Batoh Terminal counter, the reason for the ticket providers to unilaterally increase the price outside the price set by ORGANDA. It also reviewed the Tas'ir Al-Jabari of the ticket price increase at the Batoh terminal counter. The results of the study showed that the ticket price in the Batoh terminal on the eve of the Islamic holiday was marked up. Thus, the Ministry of Transportation must supervise (Tas'ir Al-Jabari) the Batoh terminal on the eve of the Islamic holiday. The ticket price in the Batoh Terminal should be based on proposal and consideration by the company and approved by ORGANDA and the Ministry of Transportation. However, the marked up price made by the bus company before the Islamic holiday was without the approval of the ORGANDA and the Ministry of Transportation.
\end{abstract}

Keywords: Ticket Prices, Mark Up, Al-Jabari Tas'ir

Abstrak: Harga tiket bus yang dijual diloket berbeda-beda, sesuai dengan fasilitas yang ditawarkan oleh pihak perusahaan bus, penumpang bisa memilih sesuai dengan bus yang ingin di tumpanginya, baik bus kelas biasa ataupun bus mewah, tentunya harga tiket bus tersebut telah disetujui oleh Organda. Akan tetapi pada penjualan tiket diterminal Batoh harga yang ditawarkan berbeda sewaktu-waktu, apalagi menjelang hari raya Islam. Harga tiket sering mengalami kenaikan harga (Mark Up) pada saat menjelang perayaan hari besar Islam di Aceh yang memberatkan masyarakat untuk membeli. Pemerintah juga sudah melakukan pengawasan terhadap pihak loket terminal Batoh dan memberikan sanksi kepada pihak loket yang melakukan kecurangan sehingga penumpang merasa dirugikan. Maka yang menjadi fokus permasalahan sebagai objek kajian dalam penelitian ini, tentang sistem penetapan harga tiket bus pada loket Terminal Batoh, penyebab pihak pengelola tiket menaikkan harga tiket bus secara sepihak diluar ketentuan harga yang ditetapkan oleh Organda, serta tinjauan Tas'ir Al-Jabari terhadap kenaikan harga tiket pada loket terminal Batoh. Dalam penelitian skripsi ini penulis menggunakan metode penilitian deskriptif analisis, dengan pendekatan kualitatif. Dari hasil penelitian harga tiket yang dijual diloket terminal Batoh pada menjelang hari raya Islam memang mengalami kenaikan harga (Mark Up) yang tidak ada persetujuan dari Organda dan Kementerian Perhubungan. sehingga perlu dari pihak Kementerian Perhubungan, melakukan pengawasan (Tas'ir AlJabari) terhadap loket terminal Batoh pada saat menjelang hari raya Islam. Dari paparan diatas dapat disimpulkan bahwa, penetapan harga tiket yang dijual diloket Terminal Batoh berdasarkan pengajuan dan pertimbangan oleh pihak perusahaan dan disetujui oleh Organda dan Kementerian Perhubungan. Kenaikan harga (Mark Up) yang dilakukan oleh perusahaan bus menjelang hari raya Islam tidak ada persetujuan oleh Organda 
dan Kementerian Perhubungan. Maka pengawasan pemerintah (Tas'ir Al-Jabari) yang dilakukan oleh pihak Kementerian Perhubungan sangat diperlukan oleh masyarakat dan pihak Kementerian Perhubungan akan memberi sanksi kepada loket yang menaikan harga.

\section{Kata kunci: Harga Tiket, Mark Up, Tas'ir Al-Jabari}

\section{PENDAHULUAN}

Transportasi menjadi peranan penting dalam pembangunan dan perkembangan suatu daerah yang berkaitan dengan mobilisasi dan pergerakan arus orang dan barang/jasa, Transportasi memiliki pengaruh dalam berbagai aspek, baik dalam aspek ekonomi, sosial, dan lingkungan. ${ }^{1}$ Indonesia merupakan negara kepulauan yang sangat luas yang tentunya menempuh jarak antar daerah/provinsi harus menggunakan transportasi yang memadai, karena bila tanpa transportasi maka akan sulit menghubungkan seluruh daerah di negara ini. ${ }^{2}$ Transportasi umum di Indonesia tersedia transportasi darat, laut, dan udara yang diharapkan akan membantu banyak orang dalam berbagai aktivitas yang mereka butuhkan.

Perekonomian masyarakat senantiasa memberikan dampak bagi sarana transportasi yang tersedia, semakin tinggi perekonomian masyarakat maka sarana transportasi umun yang digunakan yang memberi fasilitas dan pelayanan yang tinggi juga dengan membeli harga tiket yang relatif lebih mahal dari biasanya seperti menggunakan transportasi udara dan laut yang menempuh jarak dengan waktu yang cepat. Akan tetapi perekonomian masyarakat Indonesia khususnya Aceh yang mayoritas menengah kebawah maka transportasi yang digunakan yang lebih murah oleh sebab itu penggunaan transportasi darat lebih banyak digunakan oleh masyarakat Aceh.

Di Aceh, para pengusaha transportasi darat menyediakan jasa angkutan baik angkutan dalam kota (Labi-labi/Trans koetaraja, Becak, dan Ojek), angkutan antar kota dalam provinsi (Mini Bus), dan angkutan antar kota antar provinsi (Bus). Masyarakat Aceh yang keluar daerah lebih cenderung menggunakan bus, karena di Aceh pengusaha bus punya cara tersendiri untuk menarik perhatian para calon penumpang, dengan cara menyediakan fasilitas yang cukup memadai dan memanjakan penumpang, juga menyediakan bus-bus yang diimpor dari luar negeri dengan tampilan yang mewah.

Untuk biaya yang dikeluarkan oleh penumpang berbeda-beda sesuai dengan bus yang akan ditumpangi, karena bus di Aceh menawarkan beberapa jenis mulai dari Patas, Patas Executive, Super Executive, Patas VIP, Patas VIP Scania, Super VIP Scania, Super VIP High Decker, dan Double Decker. Untuk harga tiket bus di Aceh penetapannya sama dengan daerah lain yang ditetapkan oleh Organda dan disahkan oleh Kementerian Perhubungan. Organda adalah Organisai Angkutan Darat yang dibentuk pada tanggal 30 Juni 1962 yang bertempat di Selecta (Malang). Organda merupakan penggabungan organisasi-organisasi pengusaha angkutan darat. Organisasi ini bertujuan untuk membina dan mengembangkan kemampuan serta profesionalisme para anggota, untuk terwujudnya usaha angkutan darat di Indonesia yang inovatif dan berdaya saing tinggi. ${ }^{3}$

Organda menetapkan harga tiket bus berdasarkan Peraturan Menteri Perhubungan nomor 57/2014 tentang Tarif Dasar Tarif Batas Atas dan Bawah Angkutan Penumpang AKAP (Antar Kota Antar Provinsi) Kelas Ekonomi, Dalam pasal 1 ayat 1 yang berbunyi: "Tarif dasar penumpang antarkota antarprovinsi kelas ekonomi dijalan dengan mobil bus umum diatur sebagai berikut : (a) untuk wilayah I (Sumatra, Jawa, Bali, dan Nusa Tenggara) sebesar Rp. 136 pnp / km dan (b) untuk wilayah II (Kalimantan, Sulawesi, dan

1 Vivi Ria Putri dan Ritzky Karina M. R. Brahmana, 'Strategi Pengembangan Usaha Transportasi Bus (Studi Kasus Pada Perusahaan Otobus Di Lombok)' (2015) Vol. 3, No Agora 1, hlm. 1.

2 Abbas Salim, Manajemen Transportasi (Raja Grafindo Persada 1993), hlm. 3.

3 'Sejarah Organda: Http://Organda.or.Id, Di Akses Pada Tanggal 22 Februari 2018'. 
Pulau lainnya) sebesar $151 \mathrm{pnp} / \mathrm{km}^{4}$

Harga yang disebutkan diatas adalah harga yang belum ada penambahan yang dilakukan oleh Organda dan pihak perusahaan bus, pihak perusahaan bus akan mengajukan kembali harga tiket yang akan dijual, berdasarkan perhitungan harga BBM, biaya operasional, gaji sopir dan awak kendaraan, gaji petugas diloket dan biaya fasilitas tambahan didalam bus. Pihak perusahaan sangat mempertimbangkan dalam pengajuan harga tiket, mengingat saat bus memberangkat penumpang pasti ada kendala-kendala dijalanan, baik itu kerusakan mesin, kecelakaan ataupun pelemparan yang terjadi pada perbatasan Aceh dengan Sumatra utara, kejadian ini yang membuat perusahaan bus megalami kerugian. ${ }^{5}$

Organda di Aceh juga sangat mempertimbangkan hak-hak perusahaan bus, dan mempertimbangkan pendapatan daerah. Penetapan harga tiket yang dilakukan oleh Organda bertujuan untuk menstabilkan harga tiket bus, karena kuat dan lemahnya sistem perekonomian suatu negara dilihat dari kestabilan harga. ${ }^{6}$

Pada penjualan tiket diterminal Batoh harga yang ditawarkan berbeda sewaktu-waktu, didalam Islam memang tidak melarang individu maupun sekelompok dalam mengambil keuntungan dari perniagaan yang mereka lakukan. Akan tetapi, harga tiket sering mengalami kenaikan harga (Mark Up) pada saat menjelang perayaan hari besar Islam di Aceh yang memberatkan masyarakat untuk membeli, Sehingga perlu pemberdayaan bagi masyarakat agar tidak selalu dirugikan oleh pihak penjual tiket yang seharusnya harga tiket sebanding dengan fasilititas yang penumpang dapatkan. ${ }^{7}$

Dalam permasalahan yang seperti ini, maka pemerintah ikut campur tangan dalam menetukan harga dan melakukan pengawasan dalam batas-batas wajar sehingga akan menjaga kestabilan harga dan tingkat keuntungan yang saling menguntungkan dengan tidak merugikan konsumen (penumpang) yang didalam fiqh muamalah disebut Tas'ir Al-Jabari. ${ }^{8}$ Pemerintah juga mengawasi pihak loket yang melakukan kecurangan dan memberikan sanksi kepada pihak loket yang merugikan penumpang.

\section{PEMBAHASAN}

\section{Pengertian Mark Up}

Mark Up adalah penaikan harga, arti mark up sebenarnya bukanlah sesuatu yang negatif. mark up dalam bisnis diartikan sebagai selisih harga barang/jasa dengan harga jualnya. mark up ini ditambahkan kepada sebuah produk untuk menghasilkan keuntungan. Metode perhitungannya pun beragam, sistem selisih harga ini banyak diterapkan orang pada bentuk korupsi kecil-kecilan sampai menjadi korupsi besar-besaran, sehingga melekat bahwa mark up itu adalah tindakan negatif yang sangat merugikan banyak pihak yang disebut dengan mark up budget.

Mark up budget yaitu menaikkan harga penjualan barang/jasa dari nilai yang sebenarnya, yang salah satu modus korupsi. Biasanya hal tersebut menjadi dalam sebuah penjualan barang/jasa dengan cara mengelambungkan harga pada waktu waktu tertentu untuk mendapatkan keuntungan yang lebih. Padahal harga tersebut telah disepakati dan ditetapkan oleh pemerintah. ${ }^{9}$

4 'Peraturan Menteri Perhubungan Republik Indonesia Nomor PM 57 Tahun 2014' <http://jdih. dephub.go.id> accessed 27 February 2018.

5 'Hasil Wawancara Dengan Bapak Ahmad Selaku Petugas Loket Tiket Putra Pelangi Pada Tanggal 15 Desember 2017'.

$6 \quad$ Pemikiran Ekonomi Islam, Pemikiran Ekonomi Islam (Ekonosia 2003), hlm. 22.

7 Ahmad Miru, Prinsip-Prinsip Perlindungan Konsumen Di Indonesia (Raja Grafindo Persada 2011), hlm. 41.

8 Qusthoniah, 'Tafsir Al-Jabari (Penetapan Harga Oleh Negara) Dalam Koridor Fiqh Dengan Mempertimbangkan Realitas Ekonomi' (2014) Vol II, No Jurnal Syariah, hlm. 5.

9 Muhammad Makmum, 'Konstruksi Fiqh Jinayah Tentang Tindak Pidana Bisnis' (2012) Vol. 1, No Jurnal Online Unipdu, hlm. 2-3. 


\section{Dasar Hukum Pelarangan Mark Up}

Tindakan mark up harga dapat dikatakan sebuah kebohongan dan penipuan, karena tidak memberitahukan nilai yang telah ditetapkan, melainkan dengan menaikkan harga untuk memperoleh keuntungan yang lebih besar. Islam sangat melarang umatnya untuk berbohong dan menipu, sebagaimana dalam firman Allah dalam Al-Quran dalam surat Al-Maidah yang Artinya: "mengapa orang-orang alim mereka, pendeta-pendeta mereka tidak melarang mereka mengucapkan Perkataan bohong dan memakan yang haram? Sesungguhnya Amat buruk apa yang telah mereka kerjakan itu." (QS. Al-maidah : 63)

Dia berkata, "maksudnya adalah orang-orang alim di antara meraka. Betapa buruk kelakuan mereka (yakni membiarkan hal tersebut). ${ }^{10}$ Hadist Rasulullah SAW. Yang berkaitan dengan larangan menipu dalam jual beli :

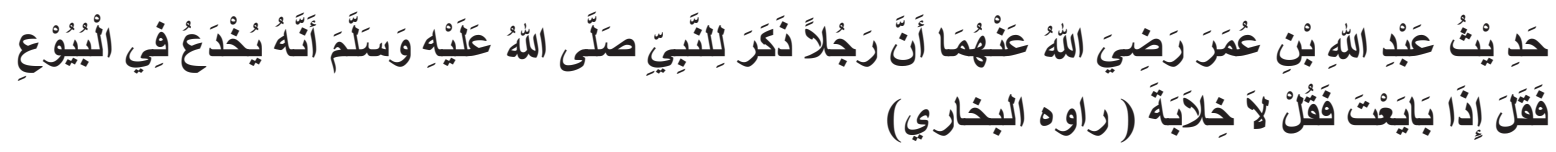

Artinya: "Hadis Abdullah bin Umar ra. Sesungguhnya seseorang bercerita kepda Nabi SAW bahwa ia selalu tertipu dalam jual beli. Lalu beliau bersabda, jika kamu membeli sesuatu maka katakana kepada penjualnya, tidak ada boleh ada penipuan sama sekali". ( HR. Bukhari). ${ }^{11}$

Dari Al-Quran dan hadis diatas menyatakan bahwa orang berbohong bukanlah umat dari pada nabi Muhammad SAW. Islam sangat melarang umatnya untuk berbohong dan menipu, namun lara ngan tersebut tidak ada sanksi hukum yang jelas, sehingga hukum bagi yang melakukan mark up harga adalah sanksi ta'zir. ${ }^{12}$

Sedangkan di Indonesia praktik Mark Up dilarang dengan berpedoman kepada:

1. Undang-Undang Nomor 5 tahun 1999 tentang Larangan Praktik Monopoli Dan Persaingan Usaha Tidak Sehat,

2. Peraturan Komisi Pengawas Persaingan Usaha (KPPU) Nomor 4 Tahun 2011 tentang pedoman pasal 5 (Penetapan Harga) Undang-Undang Nomor 5 tahun 1999 tentang Larangan Praktik Monopoli Dan Persaingan Usaha Tidak Sehat,

3. Undang-Undang Nomor 8 Tahun 1999 Tentang Perlindungan Konsumen.

\section{Pengertian Tas'ir Al-Jabari}

Secara etimologi kata tas'ir (التسعير) seakar dengan kata as-si'r ( السعير =harga) yang berarti penetapan harga. Sedangkan al-Jabari (الجبري) berarti secara paksa. Dalam fiqh Islam, ada dua istilah yang berbeda yang menyangkut harga suatu barang, yaitu as'saman dan assi'r. as-Saman, menurut ulama fiqh adalah patokan harga suatu barang. Sedangkan assi'r adalah harga yang berlaku secara aktual dipasar. Lebih lanjut ulama fiqh menyatakan bahwa fluktuasi harga suatu komoditi berkaitan berat dengan as-si'r dan as-tsaman. ${ }^{13}$

Para ulama membagi as-si'r kedalam dua macam, yaitu:

1. Harga yang berlaku secara alami, tanpa campur tangan dan ulah para pedagang. Dalam harga yang seperti ini para penjual bebas menjual barangnya sesuai dengan harga yang wajar, dengan pertimbangan keuntungannya. Pemerintah, dalam harga yang berlaku secara alami ini tidak boleh campur tangan, karena campur tangan pemerintah dalam kasus seperti ini bisa membatasi hak pedangang.

2. Harga komoditi yang ditetapkan pemerintah setelah mempertimbangkan modal

$10 \quad$ Ali bin Abi Thalhah, Tafsir Ibnu Abbas (Kumpulan Tafsir Bilma'tsur Dari Riwayat Ibnu Abbas) (Pustaka Azzam 2009), hlm. 255.

11 Ibid., hlm. 414.

12 Muhammad Makmum (n 9), hlm. 3.

13 Nasron haroen, Fiqh Muamalah (Gaya Media Pretama 2007), hlm. 139. Lihat juga Euis Amalia, 'Mekanisme Pasar Dalam Kebijakan Penetapan Harga Adil Dalam Perspektif Ekonomi Islam' (2015) 5 Al-Iqtishad: Journal of Islamic Economics <http://journal.uinjkt.ac.id/index.php/iqtishad/article/ view/2106>. 
dan keuntungan bagi pedagang dan keadaan ekonomi masyarakat. Penetapan harga dari pemerintah ini di sebut dengan at-tas'ir al-jabari.

Ada beberapa at-tas'ir al-jabari menurut pengertian yang dikemukakan oleh sebagian ulama, sebagai berikut: ${ }^{14}$

1. Menurut Imam Ibnu Irfah (Ulama Malikiyah): "Tas'ir adalah penetapan harga tertentu untuk barang dagangan yang dilakukan penguasa kepada penjual makanan dipasar dengan sejumlah dirham tertentu".

2. Menurut Syaikh Zakaria Al-Ansari (Ulama Syafi'iyah): “Tas'ir adalah perintah wali (penguasa) kepada pelaku pasar agar mereka tidak menjual barang dagangan mereka kecuali dengan harga tertentu".

3. Menurut Imam Syaukani: "Tas'ir adalah intruksi pihak penguasa atau wakilnya atau siapa saja yang mengatur urusan kaum muslimin kepada para pelaku pasar agar mereka tidak menjual barang dagangannya, kecuali sesuai dengan ketentuan harga yang telah ditetapkan oleh pemerintah dengan tujuan kemaslahatan bersama."

4. Menurut Imam Taqiyuddin An-Nabhani: "Tas'ir adalah perintah penguasa atau wakilnya atau siapa saja yang mengatur urusan kaum muslimin kepada pelaku pasar agar mereka tidak menjual barang dagangan mereka kecuali dengan harga tertentu, dan mereka dilarang menambah atas harga itu agar mereka tidak melonjakkan harga, atau mengurangi dari harga itu agar mereka tidak merugikan yang lain. Artinya mereka dilarang menambah dan mengurangi harga itu demi kemashlahatan bersama."

Dari definisi tersebut, sebenarnya maknanya hampir sama, kesamaannya ialah definisidefinisi tersebut selalu menyebutkan tiga unsur yang sama, pertama penguasa yang mengeluarkan kebijakan, kedua pihak pasar yang menjadi sasaran, ketiga penetapan harga sebagai subtansi kebijakan. ${ }^{15}$

\section{Dasar Hukum Tas'ir Al-Jabari}

Para ulama fiqh sepakat menyatakan bahwa ketentuan penetapan harga ini tidak dijumpai dalam Al-Quran. Adapun dalam hadist Rasulullah SAW. Dijumpai beberapa hadist, yang dari logika hadist itu dapat diinduksi bahwa penetapan harga itu dibolehkan. Faktor dominan yang menjadi landasan hukum tas'ir al-jabari, menurut kesepakatan ulama fiqh, adalah al-maslahah al-mursalah. ${ }^{16}$

Maslahah merupakan dalil hukum yang dapat digunakan untuk melakukan penetapan hukum terhadap suatu perkara, karena maslahah adalah faktor yang paling penting dalam hal yang sah atau tidaknya intervensi harga. Karena intervensi harga yang dilakukan bertujuan untuk mewujudkan maslahah bagi kehidupan masyarakat.

Ayat yang berkaitan dengan penetapan harga yaitu sebagai berikut, firman Allah SWT yang Artinya: "Hai orang-orang yang beriman, taatilah Allah dan taatilah Rasul (Nya), dan ulil amri di antara kamu. kemudian jika kamu berlainan Pendapat tentang sesuatu, Maka kembalikanlah ia kepada Allah (Al Quran) dan Rasul (sunnahnya), jika kamu benar-benar beriman kepada Allah dan hari kemudian. yang demikian itu lebih utama (bagimu) dan lebih baik akibatnya." (Q.S. An-Nisa: 59)

$14 \quad$ Qusthoniah (n 8), hlm. 6.

15 Ibid, hlm. 7.

16 Lebih lanjut mengenai kajian Maslahah Mursalah dapat merujuk pada beberapa artikel tersebut, Hendri Hermawan Adinugraha and Mashudi Mashudi, 'Al-Maslahah Al-Mursalah Dalam Penentuan Hukum Islam' (2018) 4 Jurnal Ilmiah Ekonomi Islam 63 <http://jurnal.stie-aas.ac.id/index.php/ jei/article/view/140>; Ahmad Qorib and Isnaini Harahap, 'Penerapan Maslahah Mursalah Dalam Ekonomi Islam' [2016] Analytica Islamica,; Imron Rosyadi, 'Pemikiran Asy-Syatibi Tentang Maslahah Mursalah' (2013) 14 Profetika: Jurnal Studi Islam 79; Nur Asiyah and Abdul Ghofur, 'Kontribusi Metode Maslahah Mursalah Imam Malik Terhadap Pengembangan Hukum Ekonomi Syari'ah Kontemporer' (2017) 27 Al-Ahkam 59 <http://journal.walisongo.ac.id/index.php/ahkam/article/view/1349>. 
Ayat diatas memberikan hak campur tangan kepada pemerintah dalam kegiatan ekonomi yang dilaksanakan oleh individu. Hal itu untuk menjaga masyarakat islam. Ayat itu juga mewajibkan atas semua umat islam untuk taat kepada pemimpin mereka. Para penganut pendapat ini menambahkan bahwa "ulil Amri" adalah mereka yang melaksanakan kedaulatan hukum syara' terhadap umat islam, meskipun disana ada perbedaan pendapat diantara para fuqaha ( ahli hukum Islam) dalam menentukan dan membalaskan syaratsyarat ulil amri.

Hadist Rasulullah SAW. Yang berkaitan dengan penetapan harga adalah sebagai berikut:

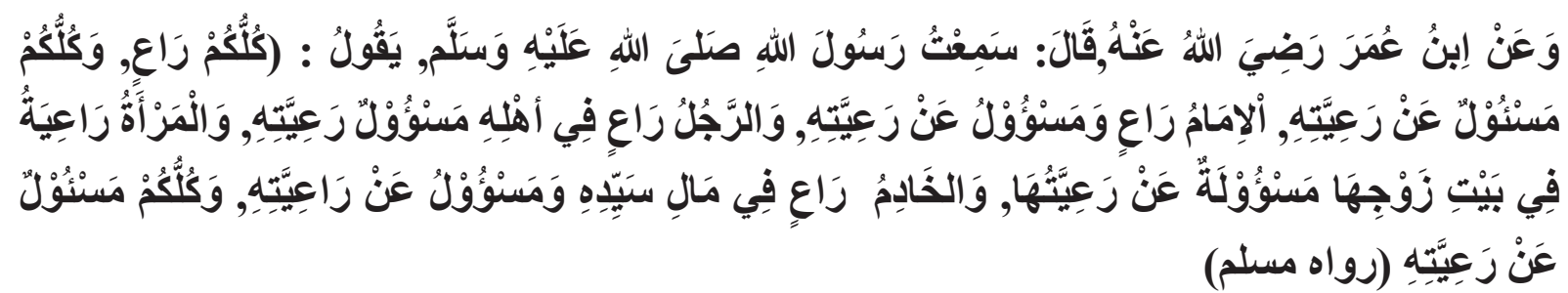

Artinya: "Ibnu Umar ra. Berkata:Aku mendengar Rasulullah SAW bersabda, "setiap kalian adalah pemimpin, maka ia akan diminta pertanggungjawaban kepemimpinannya. Maka seorang Imam adalah pemimpin rakyatnya, ia akan dimintai pertanggungjawaban tentang rakyatnya. Seorang laki-laki adalah pemimpin keluarganya dan ia akan dimintai pertanggungjawaban tentang mereka. seorang istri adalah pemimpin yang mengurusi rumah suaminya dan anaknya, ia akan dimintai pertanggungjawabannya tentang mereka. Seorang hamba sahaya adalah penanggungjawab harta tuannya dan ia akan dimintai pertanggungjawaban tentang itu. Ingatlah Setiap kalian adalah pemimpin dan setiap kalian akan dimintai pertanggungjawaban tentang kepemimpinannya". (HR. Muslim). ${ }^{17}$

Hadistini mengandung petunjuk jelas bahwa Negara bertanggung jawab terhadap terhadap semua hal yang terjadi didalamnya. Negara berhak melakukan pengawasan umum terhadap individu-individu. Negara berhak melakukan intervensi terhadap kemashlahatan dan kepentingan-kepentingan khusus demi menjaga dan melindungi kemaslahatan dan kepentingan umum serta menjamin pelaksanaan dan pengemplementasian syariat. Negara berhak melakukam pengontrolan dan pemeriksaan terhadap para pegawai dan para pemegang jabatan kekuasaaan dan kewenangan dalam semua instansi negara yang ada.

\section{Pendapat Ulama Tentang Tas'ir Al-Jabari}

Sistem pasar dalam ekonomi Islam adalah sistem pasar bebas yang di atur oleh hukum penawaran dan permintaan disertai sistem persaingan sempurna yang tidak membawa kepada kemudharatan dan kezhaliman. Ketika didapati kemudharatan dan kezhaliman, maka pemerintah diperbolehkan untuk intervensi dalam pasar.

Menurut jumhur ulama fiqih, kegiatan tas'ir al-jabari mempunyai beberapa syarat, yang pertama, komoditi tersebut menyangkut kepentingan dan keperluan masyarakat secara umum. kedua, timbulnya cara penentuan harga komoditi yang sewenang-wenang oleh pedagang. Ketiga, pemerintah harus adil. Keempat, penunjukan ahli ekonomi untuk mengkaji kelayakan kondisi pasar. Kelima, penetapan harga tidak merugikan pihak pedagang. Keenam, terjaminnya pengawasan yang dilakukan oleh pemerintah setiap waktu. ${ }^{18}$

Terdapat perbedaan pandangan ulama tentang regulasi harga yang bersumber pada perbedaan penafsiran hadist Nabi yang berkenaan dengan tas'ir, menurut Ibnu Qudamah, "didalamnya menunjukkan bahwa penetuan harga adalah Mudzalim, dan jika Zalim maka haram." Ibnu Qudamah memberikan dua alasan tidak diperkenankannya tas'ir.

17 Imam Nawawi, Riyadus Shalihin (Insan Kamil 2011), hlm. 360.

18 Qusthoniah (n 8), hlm. 11. 
1. Rasulullah tidak pernah menetapkan harga, meskipun masyarakat mengingikan hal itu.

2. Regulasi harga adalah suatu ketidakadilan yang tidak dilarang. Ini melibatkan hak milik seseorang, didalamnya setiap orang memiliki hak untuk menjual pada harga apapun, asalkan dia sepakat dengan pembelinya, sesuai dengan Firman Allah dalam Q.S. Annisa' ayat 29 yang Artinya: "Hai orang-orang yang beriman, janganlah kamu saling memakan harta sesamamu dengan jalan yang batil, kecuali dengan jalan perniagaan yang Berlaku dengan suka sama-suka di antara kamu. dan janganlah kamu membunuh dirimu Sesungguhnya Allah adalah Maha Penyayang kepadamu." (Q.S. Annisa': 29)

Imam Assyaukani berpendapat, sesungguhnya manusia berkuasa atas harga mereka, maka tas'ir adalah pembatasan bagi mereka. Dalam kondisi normal semua ulama berpendapat bahwa melakukan tas'ir adalah haram, maka dalam kondisi ketidakadilan terdapat perbedaan pandangan ulama. Imam Malik dan sebagian Syafi'iyah memperbolehkan tas'ir dalam keadaan harga melambung (ghala).$^{19}$

Ibnu Taimiyah menguji pendapat imam-imam Mazhab dan beberapa ahli fiqih, menurutnya, kontroversi antar ulama berkisar dua poin: pertama, jika terjadi harga yang tinggi dipasaran dan seseorang berusaha menetapkan harga yang lebih tinggi daripada harga yang sebenarnya, perbuatan mereka menurut mazhab Maliki harus dihentikan. Tetapi, bila para penjual mau menjual dibawah harga semestinya, ada dua pendapat dalam hal ini. Menurut Syafi'i dan penganut Ahmad bin Hanbal, seperti Abu Hafz Al-Akbari, Qadhi Abu ya'la dan lainnya, mereka tetap menentang berbagai campur tangan terhadap keadaan itu.

Kedua, dari berbeda pendapat antar para ulama adalah penetapan harga maksimum bagi para penyalur barang dagangan (dalam kondisi normal), ketika mereka telah memenuhi kewajibannya. Inilah pendapat yang bertentangan dengan mayoritas ulama, bahkan oleh maliki sendiri. Tetapi beberapa ahli, seperti Sa'id bin Musayyab, Rabiah bin Abdul Rahman, dan Yahya bin sa'id, menyetujuinya. Para pengikut Abu Hanifah berkata bahwa otoritas harus menetapkan harga, hanya bila masyarakat menderita akibat peningkatan akibat peningkatan harga itu, dimana hak penduduk harus dilindungi dari diakibatkan olehnya. ${ }^{20}$

\section{Peran Pemerintah Dalam Mengawasi Harga}

Peran pemerintah sangatlah penting untuk menjamin berjalannya mekanisme pasar secara sempurna. Rasulullah SAW telah menjalankan fungsi sebagai pengawas pasar atau al-Hisbah, yang kemudian banyak dijadikan acuan untuk peran negara terhadap pasar. Rasulullah SAW sering melakukan inspeksi kepasar untuk mengecek harga dan mekanisme pasar. Dalam mengawasi mekanisme pasar Rasulullah banyak menemukan praktik bisnis yang kurang jujur sehingga beliau menegurnya. Rasulullah SAW juga banyak memberikan pendapat, perintah ataupun larangan sehingga tercipta mekanisme pasar yang islami. Semua ini mengindikasikan dengan jelas bahwa al-Hisbah telah ada sejak masa Rasulullah SAW, mekipun nama al-Hisbah baru datang dimasa kemudian. ${ }^{21}$

Al-Hisbah adalah lembaga yang berfungsi untuk memerintahkan kebaikan sehingga menjadi kebiasaan dan melarang hal yang buruk ketika hal itu telah menjadi kebiasaan umum. Sementara tujuan al-Hisbah menurut Ibnu Taimiyah adalah untuk memerintahkan apa yang disebut dengan kebaikan dang melarangapa yang secara umum disebut dengan keburukan didalam wilayah yang menjadi kewenangan pemerintah untuk mengaturnya, mengadili dalam wilayah umum khusus lainnya, yang tak bisa di jangkau oleh institusi biasa. ${ }^{22}$

19 Ibid, hlm. 12 .

20 Ibid, hlm. 13.

21 M.Arif Hakim, 'Peran Pemerintah Dalam Mengawasi Mekanisme Pasar Dlam Perspektif Islam' (2015) Vol. 8, No Iqtishadia, hlm. 33.

Ibid, hlm. 34. 
Al-Mawardi menyatakan bahwa keberadaan sebuah pemerintah yang efektif, sangat diperlukan untuk mencegah kezhaliman dan pelanggaran. Sedangkan Ibnu Taimiyah juga menekankan Islam dan negara mempunyai hubungan yang tidak dapat dipisahkan. Satu pihak tidak dapat menjalankan peranannya dengan baik tanpa dukungan pihak lain. Proses implementasi syariah tidak akan mungkin tanpa adanya negara yang memainkan peranan penting dan negara mungkin akan terpurukdalam pemerintahan yang tidak adil dan tirani tanpa pengaruh syari'ah. ${ }^{23}$

Pemerintah mempunyai peranan penting dalam mewujudkan pasar yang islami. Intervensi pemerintah dalam pasar bukan hanya bersifat temporer dan minor, tetapi ia mengambil peranan yang besar dan penting. Pemerintah bukannya hanya menjadi sebagai wasit atas permainan pasar, tetapi ia akan berperan aktif bersama pelaku-pelaku pasar yang lain. Pemerintah dapat bertindak sebagai perencanaan, pengawasan, pengatur, produsen, sekaligus sebagai konsumen bagi kegiatan pasar. Peran pemerintah dalam pasar ini secara garis besar dapat diklasifikasikan menjadi dua bagian, yaitu : pertama, peran yang berkaitan dengan implementasi nilai dan moral Islam, kedua, peran yang berkaitan dengan teknis operasional mekanisme pasar.

Sedangkan di Indonesia pengawasan pasar juga telah di atur, supaya tidak ada warga Indonesia merasa dirugikan baik dari pihak pedagang (pelaku usaha) maupun pembeli (konsumen), hal ini di atur dalam:

1. Undang-Undang Nomor 5 Tahun 1999 Tentang Larangan Praktik Monopoli Dan Persaingan Tidak Sehat

Dalam pasal 2 Undang-undang nomor 5 tahun 1999 tentang larangan praktik monopoli dan persaingan usaha tidak sehat menyebutkan: "Pelaku usaha di Indonesia dalam menjalankan kegiatan usahanya berasaskan demokrasi ekonomi dengan memperhatikan keseimbangan antara kepentingan pelaku usaha dengan kepentingan umum". Selain itu, dalam pasal 11 juga menyebutkan: "pelaku usaha dilarang membuat perjanjian dengan pelaku usaha pesaingnya, yang bermaksud untuk mempengaruhi harga dengan mengatur produksi dan atau pemasaran suatu barang dan atau jasa, yang dapat mengakibatkan terjadinya praktik monopoli dan atau persaingan usaha tidak sehat".

Dalam pasal-pasal diatas jelas disebutkan bahwa pemerintah berhak mengawasi harga pasar supaya tidak ada pelaku usaha yang memainkan harga hanya untuk kepentingan pribadinya, yang menyebabkan konsumen ataupun pihak lain merasa dirugikan.

\section{Undang-Undang Nomor 8 Tahun 1999 Tentang Perlindungan Konsumen}

Konsumen adalah sebagai orang pemakai barang dan/atau jasa yang tersedia dalam masyarakat bagi kepentingan diri sendiri, keluarga, orang lain, maupun makhluk hidup lain yang tidak untuk diperdagangkan. Konsumen sangat berperan penting dalam dunia usaha karena konsumen sebagai target penjualan barang atau jasa oleh para pelaku usaha, oleh sebab ini pemerintah mengatur dalam undang-undang perlindungan konsumen agar konsumen mendapat perlidungan bila ada perlakuan jahat dari para pelaku usaha. Perlindungan konsumen adalah segala upaya yang menjamin adanya kepastian hukum untuk memberi perlindungan kepada konsumen.

Dalam pasal 10 (a) menyebutkan: "pelaku usaha dalam menawarkan barang dan/atau jasa yang ditujukan untuk diperdagangkan dilarang, menawarkan, mempromosikan, mengiklankan dan membuat pernyataan yang tidak benar atau menyesatkan mengenai harga atau tarif suatu barang dan atau jasa".

3. Peraturan Menteri Perhubungan Republik Indonesia Nomor Pm 36 Tahun 2016 Tentang Tarif Dasar, Tarif Batas Atas Dan Batas Bawah Penumpang Antarkota Antarprovinsi Kelas Ekonomi Di Jalan Dengan Bus Umum

23 Mustafa Edwin Nasution, Pengenalan Eksklusif Ekonomi Islam (Kencana 2007), hlm. 190. 
Kementerian Perhubungan telah menetapkan harga beserta sanksi kepada perusahaan yang menetapkan harga diatas tarif dasar yang telah ditetapkan. Dalam pasal 1 (2) menyebutkan: "tarif dasar angkutan penumpang antarkota antarprovinsi kelas ekonomi di jalan dengan mobil bus umum di atur sebagai berikut: (a) untuk wilayah I (Sumatra, Jawa, Bali, dan Nusa Tenggara) sebesar Rp. 119 per pnp/km, dan (b) untuk wilayah II (Kalimantan, Sulawesi, dan pulau lainnya) sebesar Rp. 132 per pnp/km". Dalam pasal 8 (1) juga diatur tentang sanksi yang diberikan bila ada perusahan yang melanggar pasal 1 (2) sebagai berikut: "perusahaan angkutan umum yang melakukan pelanggaran atas ketentuan yang diatur dalam peraturan ini, dikenakan sanksi admistrasi". ${ }^{24}$

Kesimpulan awal yang dapat diambil adalah bahwa penetapan harga oleh pemerintah (tas'ir al-jabari) tidak diperbolehkan, karena membatasi kebebasan terhadap masyarakat dalam melakukan aktivitas ekonomi. Akan tetapi, keadaan dipasar dapat merugikan banyak pihak maka pemerintah harus ikut menyelesaikan permasalahan yang ada dalam pasar, dengan menetapkan harga yang adil untuk mencapai kemashlahatan bersama. Demikian juga, pemerintah dapat menerapkan kebijakan-kebijakan demi kestabilan harga dipasar yang mempertimbangkan hak-hak pedagang dan juga hak-hak konsumen, yang memberi keadilan kepada setiap penduduk dalam wilayah kekuasaannya demi tercapai kemashlahatan bersama.

\section{Sistem Penetapan Harga Tiket Bus Di Terminal Batoh}

Harga tiket ditetapkan dalam Peraturan Menteri Perhubungan Republik Indonesia Nomor PM 57 Tahun 2014 Tentang Tarif Dasar Batas Atas Dan Batas Bawah Angkutan Penumpang Antarkota Antar Provinsi Kelas Ekonomi Dijalan Dengan Mobil Bus Umum. Dalam pasal 1 (1) disebutkan tarif dasar angkutan penumpang antarkota antarprovinsi kelas ekonomi dijalan dengan bus umum diatur sebagai berikut: ${ }^{25}$

\section{a. Untuk Wilayah I (Sumatera, Jawa, Bali, Nusa Tenggara) sebesar Rp.136 pnp/km}

b. Untuk wilayah II (Kalimantan, Sulawesi, dan pulau lainnya) sebesar Rp. 151 pnp/km

Selain tarif di atas di provinsi aceh juga menetapkan harga berdasarkan Peraturan Gubernur Aceh Nomor 48 Tahun 2013 Tentang Tarif Dasar Angkutan Kelas Ekonomi Dengan Bus Umum/Mobil Penumpang Umum (Mikrolet/Labi-Labi) Antarkota Dalam Provinsi. Dalam pasal 1 disebutkan tarif dasar batas angkutan penumpang kelas ekonomi dengan mobil bus umum yang sebelumnya Rp.140,- (seratus empat puluh rupiah) per penumpang per kilometer, disesuaikan menjadi Rp.160.- (seratus enam puluh rupiah) per penumpang per kilometer dan tarif bawah yang sebelumnya 86,- (delapan puluh enam rupiah) per penumpang per kilo meter menjadi Rp.99,- (Sembilan puluh Sembilan rupiah) per penumpang perkilometer.

Harga yang disebutkan diatas adalah harga yang belum ada penambahan yang dilakukan oleh Organda dan pihak perusahaan bus, pihak perusahaan bus akan mengajukan kembali harga tiket yang akan dijual, berdasarkan perhitungan harga BBM, biaya operasional, gaji sopir dan awak kendaraan, gaji petugas diloket dan biaya fasilitas tambahan didalam bus. Pihak perusahaan sangat mempertimbangkan dalam pengajuan harga tiket, mengingat saat bus memberangkat penumpang pasti ada kendala-kendala dijalanan, baik itu kerusakan mesin, kecelakaan ataupun pelemparan yang terjadi pada perbatasan Aceh dengan Sumatra utara, kejadian ini yang membuat perusahaan bus megalami kerugian.

Harga tiket yang diajukan oleh pihak perusahaan pun beragam berdasarkan fasilitas bus, antara bus yang fasilitasnya biasa dengan bus yang menyediakan fasilitas mewah bagi

$24 \quad$ Peraturan Menteri Perhubungan Republik Indonesia Nomor Pm 36 Tahun 2016 Tentang Tarif Dasar, Tarif Batas Atas Dan Batas Bawah Penumpang Antarkota Antarprovinsi Kelas Ekonomi Di Jalan Dengan Bus Umum.

25 Peraturan Menteri Perhubungan Republik Indonesia Nomor PM 57 Tahun 2014 Tentang Tarif Dasar Batas Atas Dan Batas Bawah Angkutan Penumpang Antarkota Antar Provinsi Kelas Ekonomi Dijalan Dengan Mobil Bus Umum. 
calon penumpangnya. Bila harga tersebut telah disetujui oleh pihak organda, selanjutnya organda akan mengajukan harga tersebut ke dinas perhubungan Aceh, pihak dinas perhubungan mempertimbangkan harga tiket dengan biaya operasional perusahaan bus dan juga daya beli masyarakat (calon penumpang bus), bila disetujui oleh pihak dinas perhubungan maka pihak perusahaan bus boleh mempublikasikan harga yang disetujui pada media cetak maupun media online supaya calon penumpang mengetahui harga bus yang akan ditumpanginya. Harga tiket bus tersebut berlaku sampai ada pengajuan harga tiket yang baru. ${ }^{26}$

Harga tiket bus yang dijual memang berbeda-beda harga sesuai dengan fasilitas yang calon penumpang pilih, bila penumpang memilih bus yang berfasilitas mewah (high decker dan double decker) maka harga bus yang mereka harus bayarkan juga lebih mahal dari pada bus biasa. Harga seperti ini memang sudah diatur saat perusahaan bus mengajukan tarif harga kepada pihak organda dan kementrian perhubungan. ${ }^{27}$

\section{Pihak Pengelola Loket Yang Menaikkan Harga Tiket Bus Secara Sepihak Diluar Ketentuan Harga Yang Telah Ditetapkan Oleh Pihak Organda}

Harga tiket bus telah ditentukan sesuai kesepakatan antara pihak organda dengan perusahaan bus dengan pengawasan oleh petugas kementerian perhubungan, bila pihak pengelola loket menaikkan harga tiket diluar ketentuan tersebut maka akan mendapatkan sanksi baik sanksi teguran maupun sanksi lainnya dari petugas terminal. Karena kenaikan harga diluar aturan yang telah ditetapkan akan berdampak kepada calon penumpang, sebagian calon penumpang tidak mempermasalahkan kenaikan harga pada waktu-waktu tertentu dan sebagian ada calon penumpang yang merasa sangat dirugikan atas kebijakan pihak perusahaan bus tersebut, Apalagi kenaikan harga tiket tidak ada pemberitahuan sama sekali.

Kenaikan hargabukannyahanya merugikan penumpangakan tetapijuga berdampakkepada terminal, pendapatan retribusi terminal pun akan berkurang, dengan berkurangnya calon penumpang yang langsung ke terminal untuk membeli tiket, karena calon penumpang akan lebih memilih menunggu bus dipinggir jalan dan akan menumpang bus dengan tanpa tiket. Oleh sebab inilah tindakan menaikkan harga tiket diluar ketentuan harga yang telah ditetapkan sangat dilarang oleh organda dan pihak kementerian perhubungan. ${ }^{28}$

Kenaikan harga biasanya menjelang hari raya Islam (hari raya Idul Fitri dan Idul Adha) di Aceh, kenaikan harga tiket biasa naik seminggu sebelum hari raya. Kenaikan harga tiket tersebut hanya kesepakatan para perusahaan bus, tanpa pertimbangan terhadap calon penumpang (konsumen) dan juga tidak ada persetujuan dari organda dan pihak kementerian perhubungan yang bertugas di terminal, perbuatan seperti ini sangat dilarang dan dianggap sebagai perbuatan monopoli dan persaingan usaha yang tidak sehat seperti halnya di sebutkan dalam undang-undang nomor 5 tahun 1999 tentang larangan praktik monopoli dan persaingan tidak sehat. Dalam pasal 2 disebutkan: "Pelaku usaha di Indonesia dalam menjalankan kegiatan usahanya berasaskan demokrasi ekonomi dengan memperhatikan keseimbangan antara kepentingan pelaku usaha dengan kepentingan umum".

Selain itu, dalam pasal 11 juga disebutkan: "pelaku usaha dilarang membuat perjanjian dengan pelaku usaha pesaingnya, yang bermaksud untuk mempengaruhi harga dengan mengatur produksi dan atau pemasaran suatu barang dan atau jasa, yang dapat mengakibatkan terjadinya praktik monopoli dan atau persaingan usaha tidak sehat"

Dalam Islam sangat melarang praktik monopoli yang menyebabkan kerugian terhadap kepentingan orang banyak, hadis Rasulullah SAW yang berkaitan dengan larangan praktik

26 'Hasil Wawancara Dengan Mutia Selaku Petugas Loket Dari Simpati Star Pada Tanggal 9 Juni 2018 '.

27 'Hasil Wawancara Dengan Rika Selaku Petugas Loket Dari Simpati Star Pada Tanggal 9 Juni 2018'.

28 'Hasil Wawancara Dengan Ibu Elida Selaku Petugas Kementerian Perhubungan Di Terminal Batoh Pada Tanggal 8 Juni 2018'. 
monopoli sebagai berikut:

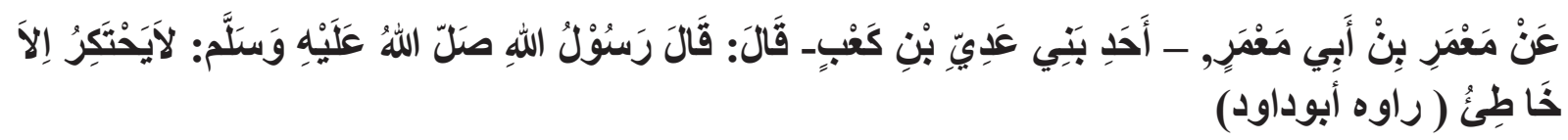

Artinya: "Dari Ma'mar bin Abu Ma'mar (salah satu anaknya Adi bin Hatim) berkata: Rasulullah SAW bersabda, Tidak memonopoli kecuali orang yang melakukan kesalahan" (HR. Abu Daud). ${ }^{29}$

Dalam Islam praktik monopoli dikenal dengan Ihtikar, ihtikar adalah menimbun suatu barang dagangan untuk menunggu melonjaknya harga. ${ }^{30}$ Ihtikar menurut ad-Duraini tidak saja menyangkut komoditi tetapi juga manfaat suatu komoditi, dan bahkan jasa dari pemberi jasa, dengan syarat "embargo" yang dilakukan pedagang dan pemberi jasa ini boleh membuat harga pasar tidak stabil, padahal komoditi , manfaat, atau jasa ini sangat diperlukan oleh masyarakat. ${ }^{31}$

Dalam masalah jasa, misalnya kalau perusahaan transportasi atau buruh sekali pun, ketika jasanya diperlukan akan tetapi mereka tidak mau memberikan jasa mereka, maka akan terjadinya "embargo" ini harga akan naik dan saat kenaikan harga barulah mereka memulai menjajakan jasa. Tindakan-tindakan semacam ini termasuk kedalam Ihtikar. ${ }^{32}$

Selain undang-undang nomor 5 tahun 1999 dan hadis di atas, praktik monopoli yang merugikan konsumen, pihak perusahaan yang tidak jujur menawarkan harga tiket bus kepada konsumen, perusahaan seperti ini juga melanggar undang-undang nomor 8 tahun 1999 tentang perlindungan konsumen, pasal 10 (a) disebutkan: "pelaku usaha dalam menawarkan barang dan/atau jasa yang ditujukan untuk diperdagangkan dilarang, menawarkan, mempromososikan, mengiklankan dan membuat pernyataan yang tidak benar atau menyesatkan mengenai harga atau tarif suatu barang dan atau jasa."

Larangan praktik monopoli dan persaingan yang tidak sehat bukan hanya dilarang dalam hukum positif (undang-undang) akan tetapi dalam Islam praktik monopoli juga merugikan banyak pihak, baik itu calon penumpang maupun pihak terminal, sehingga perbuatan seperti ini tidak dapat dibiarkan mengingat kemaslahatan bersama lebih diutamakan. Praktik monopoli biasa dilakukan oleh para pedagang pada saat para pedagang merasa sangat dibutuhkan oleh para konsumen, apalagi calon penumpang bus pada saat menjelang hari raya mereka sangat membutuhkan bus untuk pulang kekampung untuk merayakan hari raya. Akibat inilah para pengusaha bus menaikkan harga untung mendapatkan keuntungan lebih, mereka berpikir bahwa pada saat calon penumpang sangat membutuhkan tiket, pasti harga berapapun mereka akan membelinya. ${ }^{33}$

\section{Tinjauan Tas'ir Al-Jabari Terhadap Kenaikan Harga Tiket Pada Loket Terminal Batoh}

Peran pemerintah dalam mengawasi harga (Tas'ir Al-Jabari) sangat diperlukan oleh masyarakat, apa lagi harga tiket yang terus melonjak pada saat menjelang hari-hari besar Islam di Aceh terlebih hari raya Puasa (Idul Fitri) dan hari raya Haji (Idul Adha), dalam pengawasan ini yang berperan sebagai pengawas di Terminal Batoh adalah Petugas dari Kementrian Perhubungan. Sebagaimana Peraturan Menteri Perhubungan Republik Indonesia Nomor PM 132 tahun 2015 Tentang Penyelenggaraan Terminal Penumpang Jalan, Bagian Ketiga Tentang Kewenangan Penetapan Terminal Penumpang, pasal 11 menyebutkan: "Terminal penumpang sebagaimana dimaksud dalam pasal 8 dan pasal 9 ditetapkan oleh:

29 Muhammad Nashiruddin Albani, Shahih Sunan Abu Daud (Pustaka Azzam 2007), hlm. 580.

$30 \quad$ Nasron haroen (n 13), hlm. 157.

31 Ibid., hlm. 159.

32 Ibid., hlm. 160.

33 'Hasil Wawancara Dengan Ibu Elida Selaku Petugas Kementerian Perhubungan Di Terminal Batoh Pada Tanggal 8 Juni 2018' (n 28). 
a. Menteri dengan memperhatikan masukan Gubernur, untuk terminal tipe A

b. Gubernur dengan memperhatikan masukan Bupati/Walikota, untuk terminal tipe B

c. Bupati/Walikota dengan memperhatikan usulan masukan dari SKPD yang bertanggung jawab dibagian sarana dan prasarana lalu lintas dan angkutan jalan, untuk terminal tipe $\mathrm{C}$

d. Gubernur DKI Jakarta dengan memperhatikan usulan/masukan dari SKPD yang bertanggung jawab dIbidang sarana dan prasarana lalu lintas dan angkutan jalan, untuk terminal tipe B dan C di Provinsi Daerah Khusus Ibukota Jakarta.

Seperti disebutkan pada pasal 11 (a) bahwa terminal tipe A dibawah wewenang kementrian perhubungan, petugas dari kementrian perhubungan mengawasi kepada pihak loket berupa pengawasan harga yang dijual pada loket resmi di Teminal, bukan harga yang dijual oleh calo yang berada diluar terminal, Petugas Kementerian Perhubungan hanya melakukan pengawasan dalam lingkup terminal, bila ada calon penumpang yang melakukan pembelian tiket diluar terminal bukan wewanang dari Kementerian Perhubungan. Petugas kementerian perhubungan membenarkan adanya kenaikan harga yang dilakukan oleh pihak loket dari H-6 hari raya puasa (Idul Fitri), kenaikan tersebut dengan alasan bahwa pihak loket dan awak kendaraan bekerja ekstra daripada hari biasa.

Menjelang hari raya melonjaknya calon penumpang, pihakloket berkesempatan menaikkan harga tiket dari harga yang biasa dijual dihari-hari biasa, dengan keadaan terpaksa calon penumpang rela membayar mahal agar mendapatkan kursi untuk pulang kampung merayakan hari raya, sebenarnya kenaikan ini tidak boleh terjadi, karena melanggar tarif awal yang disetujui oleh pihak Organda dan Kementerian Perhubungan, akan tetapi pihak loket tetap melakukan kenaikan sehingga petugas kementerianperhubungan tidak bisa berbuat banyak karena kenaikan harga tiket pada hari-hari besar di Aceh sudah hal biasa dilakukan oleh pihak loket. ${ }^{34}$

Kebijakan menaikkan harga tiket oleh perusahaan bus yang tanpa ada koordinasi dengan organda maupun kementerian perhubungan, ini sangatlah tidak tepat, mengingat penumpang akan lebih memilih untuk menumpang bus dipinggir jalan tanpa memiliki tiket daripada menumpang bus di terminal. Bila kurangnya penumpang yang berangkat dengan bus diterminal langsung maka yang pertama akan berdampak kepada pihak terminal yang tidak mendapatkan retribusi, padahal ini sangat dibutuhkan untuk menambah khas daerah, dengan retribusi terminal bisa membangun fasilitas-fasilitas baru maupun merehab fasilitas lama yang sudah tidak layak untuk digunakan. Yang kedua efek buruk kepada penumpang sendiri, yang tidak memiliki tiket saat berangkat dengan bus, bila ada kejadian kecelakaan dijalan maka penumpang tidak akan mendapatkan jaminan asuransi baik itu perawatan bila luka-luka maupun jaminan kematian bila meninggal saat kecelakaan. ${ }^{35}$

Petugas kementerian perhubungan yang bertugas terus berupaya untuk menghambat kenaikan dengan menyediakan Bus bantuan dari dinas perhubungan Aceh dan kota Banda Aceh untuk para calon penumpang yang tidak kebagian bus yang telah disediakan oleh perusahaan bus. Petugas kementerian perhubungan menyediakan bus angkutan hari raya, yang dikelola juga oleh perusahaan bus dengan kesepakatan bekerja sama antara pihak perusahaan bus dengan petugas kementerian perhubungan, bus yang digunakan juga adalah bus yang sudah periksa layak jalan oleh Pengawas Pegawai Negeri Sipil (PPNS) di terminal tersebut. Petugas juga memperingatkan supaya pihak loket bus tidak menaikkan harga tiket kepada bus yang disediakan oleh petugas kementrian perhubungan, akan tetapi ada juga loket yang tidak mendengarkan pemberitahuan dari Kementerian Perhubungan, tetap melakukan kecurangan dengan mengambil bus bantuan untuk calon penumpang

$34 \quad$ Ibid.

35 'Hasil Wawancara Dengan Bapak Muliadi Selaku Pegawai Kementerian Perhubungan Terminal Batoh Kota Banda Aceh Pada Tanggal 8 Juni 2018'. 
tapi tetap saja menalukan penaikan harga tiket.

para calon penumpang sebagian menganggap wajar kenaikkan harga tiket bus pada menjelang hari raya, dengan alasan penumpang yang melonjak drastis dari hari-hari biasa dan pihak loketpun mengambil keuntungan, dan itu hak mereka karena banyak calon penumpang yang tidak kebaikan tiket bus. Akan tetapi banyak juga yang menyalahkan petugas kementerian perhubungan yang tidak mengontrol harga tiket pada hari-hari menjelang hari raya, mereka juga mengeluh dengan tidak adanya fasilitas tambahan padahal mereka sudah membayar mahal tiket dari harga tiket resmi yang dikeluarkan oleh organda.

Dengan menyediakan Bus oleh petugas jadi tidak ada lagi alasan dari pihak Pihak loket menaikkan harga tiket dengan alasan tidak cukup bus dalam melayani jasa pengangkutan, dengan penyediaan bus bantuan tersebut ada sedikit pengurangan harga tiket yang dinaikkan oleh pihak loket. Kenaikan harga tiket yang termasuk kedalam praktik monopoli dan persaingan tidak sehat, yang merugikan banyak masyarakat dapat dicegah dengan kesadaran masyarakat melaporkan pihak perusahaan kepada petugas keamanan diterminal ataupun petugas kementerian perhubungan, supaya pihak loket mendapatkan teguran ataupun sanksi admistrasi. ${ }^{36}$

Dalam undang-undang nomor 8 tahun 1999 tentang perlindungan konsumen, hak dan kewajiban Konsumen, pasal 4 (c) menyebutkan: "Hak atas informasi benar, jelas dan jujur mengenai kodisi dan jaminan barang dan/atau jasa."

Dalam pasal 4 (g) menyebutkan : " hak untuk dilakukan atau dilayani secara benar dan jujur serta tidak diskriminatif".

Atas dasar ini konsumen memiliki wewenang melaporkan dan bertindak bila pelaku usaha berperilaku curang atau tidak jujur tentang harga, karena harga yang ditawarkan pada tempat pemberitahuan loket terminal adalah harga yang telah disetujui oleh Organda dan Kementerian Perhubungan, sedangkan harga yang dijual pada menjelang hari raya tidak pernah di tempel/diberitahukan di tempat pemberitahuan tarif loket, di media cetak maupun di media online.

\section{KESIMPULAN}

Harga tiket yang dijual diloket Terminal Batoh Kota Banda Aceh berdasarkan pengajuan oleh pihak perusahaan bus berupa biaya yang dikeluarkan oleh pihak perusahaan bus seperti biaya operasional bus. Biaya ini akan diajukan kepada Organda, Organda akan mempertimbangkan harga harga tersebut, selanjutnya diajukan kepada Kementerian Perhubungan, bila harga tersebut disetujui maka pihak perusahaan dibolehkan untuk memberitahukan harga tiket tersebut di tempat pemberitahuan loket, media cetak, media online, dan menjual dengan harga yang disetujui.

Kenaikan harga (Mark $U p$ ) tiket yang dilakukan pada menjelang hari raya Islam tidak ada persetujuan dari Organda dan Kementerian Perhubungan, kenaikan tersebut dilakukan oleh pihak perusahaan bus karena melonjaknya penumpang pada menjelang hari raya Islam. tindakan ini melanggar Undang-Undang nomor 5 tahun 1999 Tentang Larangan Praktik Monopoli dan Persaingan Usaha Tidak Sehat. Juga melanggar Undang-Undang nomor 8 tahun 1999 tentang Perlindungan Konsumen. Karena kebijakan kenaikan harga menjelang hari raya Islam akan sangat merugikan calon penumpang.

Pengawasan pemerintah (Tas'ir Al-Jabari) yang berperan di Terminal Batoh Kota Banda Aceh Sebagai Terminal tipe A adalah kementerian perhubungan yang ditugaskan untuk mengawasi harga tiket yang dijual diterminal sangat diperlukan oleh masyarakat. Karena menjelang hari raya Islam kebijakan perusahaan bus menaikkan harga tiket sangat tidak tepat, sebagian calon penumpang menganggap kenaikan tersebut hal yang wajar, sebagian calon penumpang lainnya merasa dirugikan.

36 Ibid. 


\section{DAFTAR PUSTAKA}

Abbas Salim, Manajemen Transportasi (Raja Grafindo Persada 1993)

Adinugraha $\mathrm{HH}$ and Mashudi M, 'Al-Maslahah Al-Mursalah Dalam Penentuan Hukum Islam' (2018) 4 Jurnal Ilmiah Ekonomi Islam 63 <http://jurnal.stie-aas.ac.id/index. $\mathrm{php} / \mathrm{jei} /$ article/view/140>

Ahmad Miru, Prinsip-Prinsip Perlindungan Konsumen Di Indonesia (Raja Grafindo Persada 2011)

Ali bin Abi Thalhah, Tafsir Ibnu Abbas (Kumpulan Tafsir Bilma'tsur Dari Riwayat Ibnu Abbas) (Pustaka Azzam 2009)

Amalia E, 'Mekanisme Pasar Dalam Kebijakan Penetapan Harga Adil Dalam Perspektif Ekonomi Islam' (2015) 5 Al-Iqtishad: Journal of Islamic Economics <http://journal. uinjkt.ac.id/index.php/iqtishad/article/view/2106>

Asiyah N and Ghofur A, 'Kontribusi Metode Maslahah Mursalah Imam Malik Terhadap Pengembangan Hukum Ekonomi Syari'ah Kontemporer' (2017) 27 Al-Ahkam 59 <http://journal.walisongo.ac.id/index.php/ahkam/article/view/1349>

'Hasil Wawancara Dengan Bapak Ahmad Selaku Petugas Loket Tiket Putra Pelangi Pada Tanggal 15 Desember 2017'

'Hasil Wawancara Dengan Bapak Muliadi Selaku Pegawai Kementerian Perhubungan Terminal Batoh Kota Banda Aceh Pada Tanggal 8 Juni 2018'

'Hasil Wawancara Dengan Ibu Elida Selaku Petugas Kementerian Perhubungan Di Terminal Batoh Pada Tanggal 8 Juni 2018'

'Hasil Wawancara Dengan Mutia Selaku Petugas Loket Dari Simpati Star Pada Tanggal 9 Juni 2018'

M.Arif Hakim, 'Peran Pemerintah Dalam Mengawasi Mekanisme Pasar Dlam Perspektif Islam' (2015) Vol. 8, No Iqtishadia

Muhammad Makmum, 'Konstruksi Fiqh Jinayah Tentang Tindak Pidana Bisnis' (2012) Vol. 1, No Jurnal Online Unipdu

Muhammad Nashiruddin Albani, Shahih Sunan Abu Daud (Pustaka Azzam 2007)

Mustafa Edwin Nasution, Pengenalan Eksklusif Ekonomi Islam (Kencana 2007)

Nasron haroen, Fiqh Muamalah (Gaya Media Pretama 2007)

Pemikiran Ekonomi Islam, Pemikiran Ekonomi Islam (Ekonosia 2003)

Qorib A and Harahap I, 'Penerapan Maslahah Mursalah Dalam Ekonomi Islam’ [2016] Analytica Islamica,

Qusthoniah, 'Tafsir Al-Jabari (Penetapan Harga Oleh Negara) Dalam Koridor Fiqh Dengan Mempertimbangkan Realitas Ekonomi' (2014) Vol II, No Jurnal Syariah

Rosyadi I, 'Pemikiran Asy-Syatibi Tentang Maslahah Mursalah' (2013) 14 Profetika: Jurnal Studi Islam 79

'Sejarah Organda: Http://Organda.or.Id, Di Akses Pada Tanggal 22 Februari 2018'

Vivi Ria Putri dan Ritzky Karina M. R. Brahmana, 'Strategi Pengembangan Usaha Transportasi Bus (Studi Kasus Pada Perusahaan Otobus Di Lombok)’ (2015) Vol. 3, No Agora 1

Peraturan Menteri Perhubungan Republik Indonesia Nomor Pm 36 Tahun 2016 Tentang Tarif Dasar, Tarif Batas Atas Dan Batas Bawah Penumpang Antarkota Antarprovinsi Kelas Ekonomi Di Jalan Dengan Bus Umum 